\title{
TRANSLATION ASSESSMENT MODEL FOR INFORMATIVE TEXTS OF GERMAN LANGUAGE INTO INDONESIAN
}

\author{
Misnah Mannahali \\ State University of Makassar \\ Misna_mannahali@unm.ac.id
}

\begin{abstract}
This study aims to develop a model of assessment informative text translation German into Indonesian. The method used in this study is a qualitative content analysis approach. The results showed that the assessment model translation developed must consider the aspect of linguistics that mel lexicon, idiom, addition, subtraction transposition, levies or loans (borrowing) shrinkage or expansion, semantic aspects include the meaning referansial, meaning interpersonal and grammatical meaning, Aspect pragmatic include keruntutan mean. Besides the aspect of reasonableness phrases, terminology, spelling and punctuation should also be considered. These activities are carried out thoroughly and carefully in order to produce the desired information. Assessment model developed to have high validity and reliability so that it can be used as a model or guidelines votes informative text translations in German - language Indonesia.Kesimpulan, the results of this study would be useful to translators in general and for the lecturers in particular to be used as a reference in assessing the quality translation particularly informative text translation German into Indonesian
\end{abstract}

Keywords: Model, translation assessment, informative text

Translation is essentially defined an activity of changing the language form both written and spoken from one language (the source language) into another language (the target language) in order to obtain information or knowledge of the language concerned. This kind of activity has been carried out by humans that have evolved over time. It can certainly has positive impact on development of a nation because through translation a person can obtain a lot of knowledge.

The translation process is the activity requiring the translators' knowledge and skills because words, phrases and discourse translated do not only focus on the language level, but also on the discourse level referred to function. Translation activity starts from the understanding of words, phrases, clauses and sentence proportion, and particularly the sentence function. Therefore it is said that translating is not easy since a word from the source language is not necessarily equivalent in the target language because each language has its differences and uniqueness. This equivalence has become the main problem in translation so matching a word does not always have to be identical to the target language but the translator always tries to achieve the intended meaning.

Yusuf (1994: 8) said that to translate is identical to communicate information, messages or ideas written by the original authors. This means that the results of translation should not have additional information, message or ideas by translators but they keep conveying something desired by the authors. 
The results of translation have different qualities which depend on the ability of each translator in determining the precise equivalent as well as a variety of knowledge that can help in the process of translation. Nababan (1999: 86) said that the quality of a translation can be determined by assessing it. The result of assessment can inform us about the strengths and weaknesses of a translation with the assessment focused on the accuracy in transferring, conveying, and getting nature in the target. This kind of assessment is subjective because it involves feelings of assessors.

To minimize subjectivity in the translation assessment, an appropriate model or benchmark based on the translation theory is badly needed so that after reading the translation results, people can comment that those are great works or not. To assess the translation about informative texts, birth certificate, poem or letter of agreement has a different benchmark. The similarity is that the original work should have on hand so that the two languages involved are compared.

Machali (2000: 108) argues that the assessment of the translation is very important to create a dialectic relationship between theory and practice of translation as well as the interest of criteria and standards in assessing the translators' competence. Dialectic relationship meant is a bidirectional relationship between the qualified theory and practice of translation.

The assessment toward appropriate translation is expected to create the translation results that correspond to the original text so that the message conveyed by the author of the source language can be fulfilled and be useful for readers.

An assessment of a translation from one language to another has been conducted both nationally and internationally but there is no standard for the specific language included in the assessment of German- Indonesian translation. The assessment standard of translation still requires more in-depth study, therefore in this paper the writer proposes several alternative models or the translation assessment guidelines from German into Indonesian based on the existing models.

There are several criteria, guidelines or models that can be used in the translation assessment proposed by the experts include:

1. Kautz (2002: 284) describes the translation assessment criteria are errors in meaning (Si nnfehler), expression (Ausdruckfehler), writing (technical writing), language style (Stillolfehler), structure (theme-Rema), coherence, orthography, sentence structure and understanding culture

2. The translation evaluation criteria of Koller (2004: 214) are that: a) denotative equivalence has definition equivalent, b) connotative equivalence has equivalent meaning style-based, geographic dimension and social c) Text normative equivalence related to the text norm and language in text, d) pragmatic equivalence considering text reader and e) aesthetic formal equivalence tailored to the aesthetic aspect.

3. Machali (2009: 159) said that the translation assessment emphasizes on product rather than process. Therefore, the emphasis on aspects of linguistic accuracy, semantics and pragmatics, as well as the presence or absence, and the big or the small of the irregularities of referential meaning occurred

4. Larson (1984: 485) argues that the translation results can be assessed by referring to three: the accuracy of meaning, the clarity of translation result that can be 
understood by readers, and fairness of language used so that the translation result produced impressed as the original work and not as a result of the translation.

5. Holulin in Richard B.Noss (1992: 100) argues that there are two best criteria for assessing the quality of the translation result that is the reliability showing fidelity to the source language text and legibility demonstrating loyalty in the target language.

6. Simatupang (2000: 131) argues that besides readability and fairness, translation assessment may be directed to the meaning of the text, style and clarity.

7. Newmark (1988: 130) said that the criteria that must be considered in assessing the translation results are the understanding of vocabulary, topic, and culture as well as clarity in expressing the target language.

8. Venuti commented that translation result is categorized as good if it can be read smoothly, if it can show as if not the result of translation and it must be original in conveying author's intention.

9. Claudia Angelelli in detail accounted five basic components that must be assessed in a translation result a) the understanding of the source language text, b) linguistic competence, the ability to use grammar, spelling and punctuation, c) textual competence, understanding in using language style, cohesion and coherence, d) pragmatic competence, the ability to understand language function and socio-cultural in the use of target language.

10 Strategic competence, the ability in the use of referral sources.

From those opinions above, the conclusion can be taken that the requirements to be met by a translator in order to produce a good translation are the ability to understand the meaning of the source language text and the ability to put it into the target language well, the understanding of translation text material and cultural elements of the two languages involved and the ability to use referral sources. These indicate that the translation assessment should be guided by the above criteria. These are in accordance with the translation assessment criteria developed by a professional organization that has been published, American Translator Association (ATA) cited in Claudia that there are three essential elements that must be considered in assessing the results of the translation, namely the mastery of source language and the material presented, the ability to convey completely, the ability to build cohesion and coherence and the accuracy in the use of orthography.

The problem right now is that how the translation assessment model of informative texts from German into Indonesian required is. The research results would be useful to translators in general and for the lecturers in particular in order to be used as a reference in assessing the translation quality, especially the students' translation from German language text into Indonesian.

\section{METHOD}

The research was conducted independently from January to June 2016 to the students of the German Study Program, Faculty of Languages and Literature, Universitas Negeri Makassar in which the results were tried out to assess the translation results of the fourth semester students of German Study Program. The model obtained then was used as a guide to assess the translation results of the informative texts of German language into Indonesian. The methods used in the research were information gathering, planning, literature review, the development of first form, field test and main product revision. These activities were carried out thoroughly and carefully in order to produce the desired information. 
The arrangement of translation assessment model covers four stages, namely

a. Model draft made was based on preliminary study conducted in the form of literary study about theories related to translation, a field survey of model or guideline for assessing used by previous lecturer.

b. The tryout of translation result assessment was conducted by translator and academics to the fourth semester students of German Study Program.

c. Evaluation is that the assessment model was evaluated by the assessor in which inappropriate aspects deleted.

d. Theoretical model after being evaluated was refined based on the results obtained from the assessor.

Sampling was done by using Purposive by choosing the fourth semester students due to certain considerations. The tryout results were analyzed with a view to determine the quality of a model or guidelines.

\section{RESULTS AND DISCUSSION}

In addition to these three aspects there are several other aspects that must be considered such as the reasonableness of expression, terminology, spelling and punctuation.

There are two criteria in the translation assessment, namely

a. Meaning conveyed must be in accordance with the meaning intended by the author

b. Matters relating to the aspects of linguistics, semantics, pragmatics, reasonableness of phrases, terminology, spelling and punctuation.

The assessment was done specifically for informative text translation which covered three stages:

The first stage is the functional assessment which is in general intended to see whether there are mistakes or not. If there is no mistake, detailed assessment stage is done.

Detailed assessment is the translation assessment based on the aspects and the criteria determined in advance. It is then continued by classifying an accuracy of meaning. This classification is very important because the nature of translation is the transfer of meaning intended by the source language author as closely as possible so that in the assessment the author gives the high score percentage, 75 percent, while other aspects are only 25 percent without claiming that other aspects are not important.

The assessment method is based on the number of sentences that exist and the importance level of each aspect. Furthermore, the assessment percentage each aspect is determined by comparing it with the number of sentences translated. After that, determining criteria of the informative text assessment based on predetermined. Here is a translation assessment criteria informative text 
Table 1. Criteria of the Informative Text Assessment

\begin{tabular}{|c|c|c|c|}
\hline No & Aspects & Criteria & Percentage \\
\hline A. & $\begin{array}{l}\text { The accuracy of meaning } \\
\text { equivalence covers: } \\
\text { 1. Aspects of Linguistics } \\
\text { a. Lexicon } \\
\text { b. Idiom } \\
\text { c. Addition } \\
\text { d. Reduction } \\
\text { e. Transposition } \\
\text { f. Modulation } \\
\text { g. Collection } \\
\text { h. Official Translation } \\
\text { i. Depreciation and Expansion } \\
\text { 2. Aspects of Semantics } \\
\text { a. Referential meaning } \\
\text { b. Interpersonal meaning } \\
\text { - Language style } \\
\text { - Connotative } \\
\text { - Denotative } \\
\text { c. Grammatical meaning } \\
\text { 3. Pragmatic Aspect } \\
\text { - Meaning Equivalence }\end{array}$ & $\begin{array}{l}\text { True } \\
\text { True } \\
\text { Reasonable } \\
\text { True } \\
\text { True } \\
\text { True } \\
\text { True } \\
\text { True } \\
\text { Reasonable } \\
\text { Change / Wrong } \\
\text { Formal/Neutral } \\
\text { Informal/Familiar } \\
\text { True } \\
\text { True } \\
\text { True } \\
\text { Equivalent/No }\end{array}$ & $\begin{array}{l}10 \\
25\end{array}$ \\
\hline B. & The Reasonableness of Expression & Reasonable/ Literal & 10 \\
\hline C. & Terminology & True / Standard & 5 \\
\hline D. & Spelling & True / Standard & 5 \\
\hline E. & Punctuation & True & 5 \\
\hline Total & & & 100 \\
\hline
\end{tabular}

The Assessment of the criteria above uses such indicators as in table 2 below:

Table 2. Assessment Criteria Indicators Used

\begin{tabular}{|c|c|c|c|}
\hline Aspect & Criteria & Indicator & Score \\
\hline A 1 & $\begin{array}{l}\text { True } \\
\text { (a,c,d,e,f,g,h,i) } \\
\text { Reasonable (b) }\end{array}$ & $\begin{array}{l}\text { - In accordance with the rules of } \\
\text { the Indonesian language } \\
\text { - Naturally, the translation is not } \\
\text { rigid }\end{array}$ & 10 \\
\hline A 2 . & $\begin{array}{l}\text { a. Change } \\
\text { Mistake } \\
\text { b. 1. - Formal } \\
\quad \text { - Neutral } \\
\text { - Informal }\end{array}$ & $\begin{array}{l}\text { - } 75 \text { percent of the translation } \\
\text { does not change the meaning } \\
\text { - } \quad \text { In accordance with the formal } \\
\text { language } \\
\text { - } \quad \text { Generally used } \\
\text { - } \\
\text { - Grammatical structure and } \\
\text { vocabulary simple }\end{array}$ & $\begin{array}{l}15 \\
15\end{array}$ \\
\hline
\end{tabular}




\begin{tabular}{|c|c|c|c|}
\hline & $\begin{array}{l}\text { - Familiar } \\
\text { 2. True } \\
\text { 3. True } \\
\text { c. True }\end{array}$ & $\begin{array}{ll}- & \text { Simple Sentences } \\
\text { - } & \text { Meaning received positive } \\
\text { reaction } \\
\text { - }\end{array}$ & 15 \\
\hline A 3. & Equivalent & $\begin{array}{l}75 \text { percent of the translation is } \\
\text { equivalent to meaning }\end{array}$ & 25 \\
\hline B & Reasonable & $\begin{array}{l}\text { - } 75 \text { percent of the translation is } \\
\text { not rigid }\end{array}$ & 10 \\
\hline $\mathrm{C}$ & $\begin{array}{l}\text { True } \\
\text { Standard }\end{array}$ & $\begin{array}{l}\text { - } 75 \text { percent correctly in accordance } \\
\text { with the enhanced Indonesian } \\
\text { spelling system } \\
\text { - In accordance with a standardized } \\
\text { terminology }\end{array}$ & 5 \\
\hline D & $\begin{array}{l}\text { True } \\
\text { Standard }\end{array}$ & 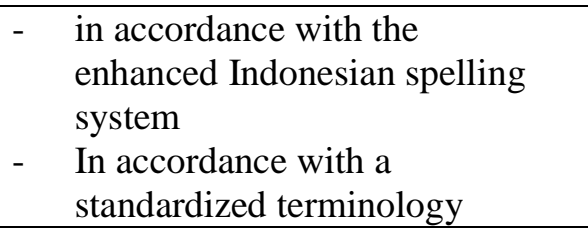 & 5 \\
\hline E & True & $\begin{array}{l}\text { in accordance with the } \\
\text { enhanced Indonesian spelling } \\
\text { system }\end{array}$ & 5 \\
\hline
\end{tabular}

Information:
A1 : Linguistic Aspect
A3 : Pragmatics Aspect
A2 : Semantics Aspect
B : The Reasonableness of Expression
C : Terminology
D : Spelling
E : Punctuation

Further translation assessment results were incorporated into categories with indicators that have been determined as shown in Table 3 below:

\begin{tabular}{|c|c|c|l|}
\hline No & Category & Score & \multicolumn{1}{|c|}{ Indicators } \\
\hline 1. & $\begin{array}{l}\text { Highly Accepted } \\
\text { Translation }\end{array}$ & $86-96$ & $\begin{array}{l}\text { No mistake in meaning, reasonable } \\
\text { expression, as if not translation, no } \\
\text { spelling error, appropriate use of term and } \\
\text { punctuation. }\end{array}$ \\
\hline 2. & Accepted Translation & $70-85$ & $\begin{array}{l}\text { No mistake in meaning, rigidly literal } \\
\text { translation, grammatical error, } \\
\text { misspelling, punctuation mistake but less } \\
\text { than 25 percent. }\end{array}$ \\
\hline
\end{tabular}




\begin{tabular}{|l|c|c|l|}
\hline 3. & $\begin{array}{c}\text { Fairly Accepted } \\
\text { Translation }\end{array}$ & $54-69$ & $\begin{array}{l}\text { known as translation result, rigidly literal } \\
\text { translation, errors in idiom/grammar but } \\
\text { not more than 25\%, one or two non- } \\
\text { standard terms }\end{array}$ \\
\hline 4. & $\begin{array}{l}\text { Unaccepted } \\
\text { Translation }\end{array}$ & $<53$ & $\begin{array}{l}\text { easily known as translation result, more } \\
\text { than 25 percents of rigidly literal } \\
\text { translation, meaning mistake and more } \\
\text { than 25 percents errors in using terms }\end{array}$ \\
\hline
\end{tabular}

\section{CONCLUSIONS}

Translation assessment model can be divided into three namely qualitative, quantitative, and mixed. Translation assessment model or guideline is badly needed to assess translation in order to know the quality. Assessment model of informative is very necessary because the text is very much needed in the fields of science and technology. Assessment model developed has high validity and reliability so that it can be used as a model or guideline for translation assessment of informative text in German - Indonesian2.

\section{REFERENCES}

Albrecht, Joern.Uebersetzung und Linguistik, Grundlagen der Uebersetzungsforschung. Tuebingen: Gunter Narr Verlag. 2005.

Angelelli V. Caludia, Jacobsom E. Holly. Testing and Assesment in Translatiom and Interpreting Studies, a Call for Dialogue Between Research and Practice. Amsterdam: John Benyamin Publishing Company, 2009.

Haliday M.A.K, Ruguiya Hasan. Language Context and Text : Aspek of Language in Social Semiotik Perspective, Victoria:Deakin Univeristy Press, 1985.

Hohulin, E. Lou. “Gramatika Teks dalam Penerjemahan”.Sepuluh makalah Mengenai Penerjemahan. ed. Richard B. Noss terjemahan Kentjanawati, Jakarta : Rebia Indah Prakasa, 1992.

House, Juliane. A Model of Translation Quality Assesment: A Model Revisted. Tubingen Narr: TBL Berlag, 1997

Larson, Mildred L. Penerjemahan Berdasar Makna: Pedoman untuk Pemadanan antar Bahasa. Alih Bahasa: Kentjanawati Taninan, Jakarta : Arcan,1989

Machali, Rochayah. Pedoman Bagi Penerjemah. Jakarta: Grasindo, 2000

Moeliono Anton. Kata Pengantar, dalam Mildred Larson. Penerjemahan Berdasar Makna: Pedoman Untuk Pemadanan Makna, Terjemahan Kencanawati Taniran. Jakarta: Arcan , 1989

Nababan, Rudolf. Teori Menerjemah Bahasa Inggeris. Jogyakarta: Pustaka Pelajar, 2003. Newmark, Peter. A Textbook of Translation. London: Pretice Hall Internation, 1988.

Simatupang, Maurits D.S. Pengantar Teori Terjemahan. Jakarta: Direktorat Jendral Pendidkan Tinggi Departemen Pendidikan Nasional, 2000

Venuti, Lawrence.Introduction, Rethinking Translation: Discourse, Subjective, Ideologi.London: Routlage, 1992

Yusuf, Suhendra. Teori Terjemah Pengantar ke Arah Pendekatan Linguistik dan Sosiolinguistik. Bandung: Mandar Maju, 1994 